\title{
Character Association Studies for Various Characters in Local Cucumber (Cucumis sativus L.) under Subtropical Regions of Jammu
}

\author{
Raman Thappa*, Sanjeev Kumar and R. K. Samnotra \\ Division of Vegetable Science and Floriculture, Sher-e-Kashmir University of Agriculture \\ Science and Technology of Jammu (J\&K) 180009, India \\ *Corresponding author
}

\section{A B S T R A C T}

\begin{abstract}
The present investigation was carried out at Vegetable Experimental Farm-I, Division of Vegetable Science and Floriculture, FOA, Chatha, SKUAST-J, during the year 2018-2019. The experiment was laid out in Randomized Complete Block Design with three replications. The Analysis of Variance revealed significant differences among the genotypes for all the characters studied. The Phenotypic Coefficient of Variance (PCV) and Genotypic Coefficient of Variation (GCV) were high for number of fruits/vine and fruit yield/vine. High estimates of heritability were recorded for number of seeds/fruit, fruit yield/vine, average fruit weight, vine length, 1000 seed weight, fruit length, number of fruits/vine, fruit diameter, days to first harvest, days to $50 \%$ flowering, node number at which first female flower appears, total soluble solids and days to first female flowering. High genetic gain as percentage of mean was observed for fruit yield/vine, number of fruits/vine, number of seeds/fruit, node number at which first female flower appears, 1000 seed weight, fruit yield/hectare, fruit length, average fruit weight and fruit diameter.The traits viz. number of fruits/vine, fruit yield/vine gave high heritability, genetic advance and GCV indicating that these are controlled by additive gene action and could be improved by direct selection. In general, genotypic correlations were higher in magnitude than phenotypic ones. Fruit yield/hectare showed negatively significant correlation with days to $50 \%$ flowering while positive significant correlation with days to first harvest and number of fruits/vine. Maximum positive direct effect towards fruit yield/hectare was exerted by days to first female flowering followed by fruit yield/vine, total soluble solids, days to $50 \%$ flowering, number of seeds/fruit and number of fruits/vine.
\end{abstract}

\section{Keywords}

Cucumber, Genetic variability, Heritability, Correlation, Path coefficient

Article Info

Accepted:

24 September 2020 Available Online: 10 October 2020

\section{Introduction}

Cucumber (Cucumis sativus L., $2 \mathrm{n}=2 \mathrm{x}=14$ ) also called "Khira" belonging to family Cucurbitaceae, is a warm season vegetable crop grown under tropical and sub-tropical regions. It is one of the most important summer vegetable crops grown both under open field and protected conditions throughout India and world. Cucumber is considered as second most widely cultivated cucurbit after watermelon. The center of origin of cucumber is India and Cucumis sativus L. var. hardwickii, a wild relative of 
cucumber is its progenitor, which is found in the Himalayan foothills of Nepal. Cucumber has tremendous economic and dietic importance. It is grown for its tender fruits, which are consumed either raw as salad (Arunkumar et al., 2011), cooked as vegetable or as pickling cucumber in its immature stage. It is a low energy and high water content vegetable, and it is also a rich source of vitamin $B$ and $C$, carbohydrates, calcium and phosphorus (Yawalkar, 1985). Fruits of cucumber are used as an astringent and antipyretic, prevents constipation and also useful in jaundice and indigestion. As deep cooling effect, the demand of cucumber is increasing day by day. Everyone is fond of eating this vegetable as raw for refreshment, especially as salad with fast food (Reshma, 2011). The seed oil also has antipyretic property. Seeds contain oil, which is helpful for brain development and body smoothness. Hence, it is being used in Ayurvedic preparations (Robinson and Decker's Walter, 1999). Besides this, the whole fruit is used in cosmetic and soap industries. Its juice is still useful for rheumatic conditions and healthy growing hair (Khulakpam et al., 2015).

\section{Materials and Methods}

The experimental material comprised of 21 diverse genotypes of local cucumber collected from different areas of J\&K viz. Cucumber selection-1 [Local Selection (S1)], Cucumber selection-2 [Local Selection (S2)], Cucumber selection-3[Local Selection from Khera, Udhampur], Cucumber selection-4[Barnai, Jammu], Cucumber selection-5[Advance Breeding line (ABL: 2017-7)], Cucumber selection-6 [Advance Breeding line (ABL: 2017-4)], Cucumber selection-7 [Advance Breeding line (ABL: 2017-10)], Cucumber selection-8 [Durga seeds], Cucumber selection-9 [Kisan Kheti], Cucumber selection-10 [Local selection from Udhampur (Chenani)], Cucumber selection-11 [Local selection from Udhampur (Jallow)], Cucumber selection-12 [Advance Breeding line (ABL: 2017-9)], Cucumber selection13[Green Express Global Seeds], Cucumber selection-14 [Raunak seeds], Cucumber selection-15 [RangaBalanda, Udhampur], Cucumber selection-16 [Pancheri, Udhampur], Cucumber selection17[Khirmoo, Udhampur], Cucumber selection-18[Kora, Udhampur], Cucumber selection-19[Rajouri], Cucumber selection-20 [Srinagar (Tral)] and Cucumber selection-21 [Lander, Udhampur] were transplanted in Randomized Complete Block Design with three replications during 2018 - 2019 in a plot size of $1.20 \times 1.20 \mathrm{~m}$ with spacing of $1.0 \mathrm{~m} \times$ $1.0 \mathrm{~m}$. All the recommended cultural practices were followed during the growth and development period of the crop to raise a healthy crop.

The averaged values of all the 4 plants of various genotypes were subjected to statistical analysis at the computer lab of Sher-eKashmir University of Agricultural Sciences and Technology of Jammu, Chatha, Jammu and were analyzed as per Gomez and Gomez (1976). The genotypic and phenotypic coefficients of variability were calculated as per the method suggested by Burton and De Vane (1953). Heritability (broad sense) was estimated as per Allard, 1960 a. Heritability percentage was categorized as per Robinson (1966). Genetic advance was calculated as per Allard (1960 b). Genetic advance expressed as per cent of population mean was calculated by the formula suggested by Johnson et al., (1955 a).

\section{Results and Discussion}

The analysis of variance for various characters in cucumber showed significant differences among the genotypes for all the traits studied and revealed the existence of substantial amount of variability in the 
germplasm. The knowledge of genetic coefficient of variation is necessary for improvement of a crop which helps to measure the extent of genetic variability in the characters among genotypes and provides a means to compare the genetic variability present in the various characters.

The phenotypic and genotypic coefficients of variability were found to be high for number of fruits per vine $(22.00 \%$ and $20.69 \%)$ and fruit yield per vine $(21.13 \%$ and $21.11 \%)$, moderate for node number at which first female flower appears (19.29\% and 17.42 $\%)$, number of seeds per fruit $(16.02 \%$ and $16.01 \%), 1000$ seed weight $(14.97 \%$ and $14.59 \%)$, fruit length (14.53\% and $13.83 \%)$, fruit diameter (13.49\% and $12.47 \%$ ) and average fruit weight (12.02\% and $11.99 \%)$ whereas it was low for vine length $(9.78 \%$ and $9.54 \%)$, days to $50 \%$ flowering $(7.43 \%$ and $6.79 \%)$, days to first harvest $(7.32 \%$ and $6.69 \%)$ and days to first female flowering $(6.95 \%$ and $6.17 \%)$. Coefficients of variability varied in magnitude from character to character (either low, moderate or high). Therefore, it indicated that there was a great variability in the experimental material used (Table 1). All the characters showed less difference between the GCV and PCV values implying variability due to genetic constitution. This suggested that selection could be effective on the basis of phenotypic characters with chances of success. The results are in line with the findings of Kandasamy (2017), Pal et al., (2017), Ahirwar et al (2017), Ranjan et al., (2015) and Choudhary et al., (2015).

The heritable variation can be estimated with accuracy when heritability is studied along with genetic advance (GA). High heritability coupled with high genetic advance offers the most effective criteria for selection (Johnson et al., 1955). Genetic advance as percentage of mean varied from $11.31 \%$ for days to first female flowering to $43.43 \%$ for fruit yield/vine. It was found high for fruit yield per vine $(43.43 \%)$, number of fruits per vine $(40.10 \%)$, number of seeds per fruit (32.96 $\%)$, node number at which first female flower appears (32.39\%), 1000 seed weight (29.30 $\%)$, fruit yield per hectare $(28.61 \%)$, fruit length $(27.11 \%)$, average fruit weight $(24.64$ $\%)$ and fruit diameter $(23.76 \%)$, indicating additive gene action control for the inheritance of these traits and these traits are likely to respond more to selection. The results are in accordance with findings of Pal et al., (2017), Ahirwar et al., (2017), Ranjan et al., (2015), Basavarajeshwari et al., (2014), Kumar et al., (2013), Gaikwad et al., (2011), Shukla et al., (2010), Yogesh et al., (2009).

High heritability was observed for traits viz. number of seeds per fruit $(95.90 \%)$, fruit yield per vine $(95.80 \%)$, average fruit weight (95.50\%), vine length $(95.10 \%), 1000$ seed weight $(93.00 \%)$, fruit length $(90.60 \%)$, number of fruits per vine $(88.50 \%)$, fruit diameter $(85.50 \%)$, days to first harvest $(83.60 \%)$, days to $50 \%$ flowering $(83.40 \%)$, node number at which first female flower appears $(81.50 \%)$, total soluble solids $(81.20$ $\%)$, days to first female flowering $(79.00 \%)$ and fruit yield per hectare $(66.30 \%)$ was obtained. This realizes that selection can be done quickly for the characters having high heritability. The above results are in accordance with the earlier work of Ahirwar et al., (2017), Pal et al., (2017) Kandasamy (2017), Pal et al., (2016), Ranjan et al., (2015) and Kumar et al., (2013).

In any breeding programme yield (dependent variable) is the end product of interaction of many contributing characters (independent variables) and selection in such programmes is effective only when based on such independent variables. In the present study the genotypic correlation coefficients were higher in magnitude than the corresponding 
phenotypic correlation coefficients indicating strong inherent association among these characters (Table 2). The phenotypic and genotypic correlations among different characters showed that days to $50 \%$ flowering was negatively and significantly correlated with fruit yield per hectare and average fruit weight at both phenotypic and genotypic levels, whereas it was positively and significantly correlated with number of fruits per vine and days to first harvest both at phenotypic and genotypic levels, while vine length was positively and significantly correlated at genotypic level only. Days to first female flowering was negatively and significantly correlated with days to first harvest at both phenotypic and genotypic levels, whereas it was positively and significantly associated with node number at which first female flower appears at genotypic level only. Node number at which first female flower appears was positively and significantly correlated with number of seeds per fruit at both phenotypic and genotypic levels. Days to first harvest was negatively and significantly correlated with fruit diameter at both phenotypic and genotypic levels. Fruit length was positively and significantly correlated with fruit diameter at both phenotypic and genotypic levels. Fruit diameter was positively and significantly associated with fruit yield per hectare, fruit yield per vine at both phenotypic and genotypic levels, it was negatively and significantly correlated with total soluble solids, 1000 seed weight and number of seeds per fruit at phenotypic and genotypic levels, while number of fruits per vine at genotypic level only. Average fruit weight was positively and significantly correlated with fruit yield per hectare and fruit yield per vine, whereas it was negatively and significantly correlated with vine length, total soluble solids and number of fruits per vine at phenotypic and genotypic levels. Number of fruits per vine was positively and significantly correlated with fruit yield per hectare, fruit yield per vine, number of seeds per fruit and total soluble solids at both phenotypic and genotypic levels. Vine length was positively and significantly correlated with 1000 seed weight at phenotypic and genotypic levels. Number of seeds per fruit was positively and significantly associated with fruit yield per hectare, fruit yield per vine and 1000 seed weight at phenotypic level, while it was significantly associated with fruit yield per hectare and 1000 seed weight at genotypic level only. 1000 seed weight was positively and significantly correlated with fruit yield per hectare, fruit yield per vine and total soluble solids at both phenotypic and genotypic levels. Total soluble solid was positively and significantly associated with fruit yield per vine both at phenotypic and genotypic levels, while with fruit yield per hectare at genotypic level only. Fruit yield per vine was positively and significantly correlated with fruit yield per hectare at both phenotypic and genotypic levels. The results corroborate with the findings of earlier work by Pal et al., (2017), Ahirwar et al (2017), Khan et al., (2015), Veena et al., (2013), Kumar et al., (2013), Bhardwaj and Kumar (2012), Hasan et al., (2012), Ullah et al., (2012), Kumar et al., (2011), Arunkumar et al., (2011).

The knowledge of correlation coefficients alone is often misleading as it may always be not true. For this the path analysis, which reveals the direct and indirect association is the most reliable method. The results of path analysis (Table 3) revealed that days to first female flowering had maximum positive direct contribution towards fruit yield/hectare, followed by days to first female flowering $(0.54)$, fruit yield per vine $(0.44)$, total soluble solids (0.44), days to $50 \%$ flowering (0.26), number of seeds per fruit (0.24) and number of fruits per vine $(0.22)$. 
Table.1 Estimates of variability parameters for different characters in local cucumber (Cucumis sativus L.)

\begin{tabular}{|c|c|c|c|c|c|c|c|}
\hline \multirow[t]{2}{*}{ Characters } & \multirow[t]{2}{*}{ Mean \pm SE $(\mathrm{m})$} & \multirow[t]{2}{*}{ Range } & \multicolumn{2}{|c|}{$\begin{array}{l}\text { Coefficient of } \\
\text { variability }\end{array}$} & \multirow{2}{*}{$\begin{array}{c}\text { Heritability } \\
\text { (bs) } \\
(\%)\end{array}$} & \multirow[t]{2}{*}{$\begin{array}{l}\text { Genetic } \\
\text { advance }\end{array}$} & \multirow{2}{*}{$\begin{array}{c}\text { Genetic gain } \\
\text { as } \% \text { age of } \\
\text { mean }\end{array}$} \\
\hline & & & PCV & GCV & & & \\
\hline Days to $50 \%$ flowering & $30.35 \pm 0.53$ & $27.33-35.67$ & 7.43 & 6.79 & 83.40 & 3.88 & 12.77 \\
\hline Days to first female flowering & $31.30 \pm 0.57$ & $27.67-36.00$ & 6.95 & 6.17 & 79.00 & 3.54 & 11.31 \\
\hline $\begin{array}{l}\text { Node number at which first female flower } \\
\text { appears }\end{array}$ & $7.24 \pm 0.35$ & $4.42-10.17$ & 19.29 & 17.42 & 81.50 & 2.35 & 32.39 \\
\hline Days to first harvest & $50.70 \pm 0.87$ & $46.33-61.33$ & 7.32 & 6.69 & 83.60 & 6.39 & 12.61 \\
\hline Fruit length (cm) & $13.53 \pm 0.35$ & $9.86-18.29$ & 14.53 & 13.83 & 90.60 & 3.67 & 27.11 \\
\hline Fruit diameter (cm) & $4.54 \pm 0.13$ & $3.64-6.17$ & 13.49 & 12.47 & 85.50 & 1.08 & 23.76 \\
\hline Average fruit weight (g) & $203.81 \pm 0.97$ & $157.31-252.23$ & 12.02 & 11.99 & 95.50 & 50.23 & 24.64 \\
\hline Number of fruits per vine & $8.10 \pm 0.35$ & $5.58-12.17$ & 22.00 & 20.69 & 88.50 & 3.25 & 40.10 \\
\hline Vine length (m) & $1.80 \pm 0.02$ & $1.44-2.24$ & 9.78 & 9.54 & 95.10 & 0.34 & 19.16 \\
\hline Number of seeds per fruit & $244.84 \pm 0.82$ & $176.00-308.67$ & 16.02 & 16.01 & 95.90 & 80.71 & 32.96 \\
\hline 1000 seed weight $(g)$ & $24.60 \pm 0.48$ & $17.91-29.13$ & 14.97 & 14.59 & 93.00 & 7.21 & 29.30 \\
\hline Total soluble solids (brix) & $3.01 \pm 0.08$ & $2.75-4.00$ & 11.03 & 9.94 & 81.20 & 0.56 & 18.46 \\
\hline Fruit yield per vine (kg) & $1.47 \pm 0.02$ & $0.99-2.24$ & 21.13 & 21.11 & 95.80 & 0.64 & 43.43 \\
\hline Fruit yield per hectare (q/ha) & $143.74 \pm 12.16$ & $99.00-224.33$ & 24.65 & 18.50 & 66.30 & 41.12 & 28.61 \\
\hline
\end{tabular}


Table.2 Phenotypic (P) and Genotypic (G) correlation coefficients among various characters in local cucumber (Cucumis sativus L.)

\begin{tabular}{|c|c|c|c|c|c|c|c|c|c|c|c|c|c|c|c|}
\hline Traits & & DFF & DFFF & NNFFF & DFH & FL & FD & AFW & NFPV & VL & NSPF & $1000 \mathrm{SW}$ & TSS & FYPV & FYPH \\
\hline DFF & $\begin{array}{l}P \\
G\end{array}$ & $\begin{array}{l}- \\
-\end{array}$ & $\begin{array}{l}0.148 \\
0.233\end{array}$ & $\begin{array}{c}0.006 \\
-0.031\end{array}$ & $\begin{array}{l}0.446 * * \\
0.508 * *\end{array}$ & $\begin{array}{l}-0.093 \\
-0.069\end{array}$ & $\begin{array}{l}0.090 \\
0.128\end{array}$ & $\begin{array}{l}-0.262^{*} \\
-0.287 *\end{array}$ & $\begin{array}{l}0.251^{*} \\
0.261^{*}\end{array}$ & $\begin{array}{c}0.238 \\
0.259^{*}\end{array}$ & $\begin{array}{l}0.150 \\
0.163\end{array}$ & $\begin{array}{l}0.193 \\
0.217\end{array}$ & $\begin{array}{l}0.067 \\
0.093\end{array}$ & $\begin{array}{l}-0.169 \\
-0.186\end{array}$ & $\begin{array}{l}-0.244^{*} \\
-0.261 *\end{array}$ \\
\hline DFFF & $\begin{array}{l}P \\
G\end{array}$ & & $\begin{array}{l}- \\
-\end{array}$ & $\begin{array}{c}0.217 \\
0.333 * *\end{array}$ & $\begin{array}{l}-0.601 * * \\
-0.689 * *\end{array}$ & $\begin{array}{l}-0.081 \\
-0.109\end{array}$ & $\begin{array}{l}0.032 \\
0.087\end{array}$ & $\begin{array}{l}0.054 \\
0.070\end{array}$ & $\begin{array}{l}-0.046 \\
-0.087\end{array}$ & $\begin{array}{l}0.113 \\
0.107\end{array}$ & $\begin{array}{l}0.129 \\
0.147\end{array}$ & $\begin{array}{l}-0.189 \\
-0.213\end{array}$ & $\begin{array}{l}0.016 \\
0.021\end{array}$ & $\begin{array}{l}-0.066 \\
-0.078\end{array}$ & $\begin{array}{l}-0.023 \\
-0.084\end{array}$ \\
\hline NNFFF & $\begin{array}{l}P \\
G\end{array}$ & & & $\begin{array}{l}- \\
-\end{array}$ & $\begin{array}{l}-0.082 \\
-0.053\end{array}$ & $\begin{array}{l}0.070 \\
0.078\end{array}$ & $\begin{array}{l}-0.155 \\
-0.217\end{array}$ & $\begin{array}{l}-0.012 \\
-0.017\end{array}$ & $\begin{array}{l}-0.076 \\
-0.090\end{array}$ & $\begin{array}{l}-0.120 \\
-0.103\end{array}$ & $\begin{array}{c}0.311^{*} \\
0.346^{*} *\end{array}$ & $\begin{array}{l}-0.031 \\
-0.044\end{array}$ & $\begin{array}{c}0.009 \\
-0.003\end{array}$ & $\begin{array}{l}-0.207 \\
-0.230\end{array}$ & $\begin{array}{l}-0.191 \\
-0.133\end{array}$ \\
\hline DFH & $\begin{array}{l}P \\
G\end{array}$ & & & & $\begin{array}{l}- \\
-\end{array}$ & $\begin{array}{l}-0.169 \\
-0.179\end{array}$ & $\begin{array}{l}-0.491 * * \\
-0.591 * *\end{array}$ & $\begin{array}{l}0.072 \\
0.081\end{array}$ & $\begin{array}{l}-0.077 \\
-0.090\end{array}$ & $\begin{array}{l}0.226 \\
0.240\end{array}$ & $\begin{array}{l}-0.056 \\
-0.064\end{array}$ & $\begin{array}{l}-0.118 \\
-0.133\end{array}$ & $\begin{array}{l}-0.049 \\
-0.023\end{array}$ & $\begin{array}{l}-0.035 \\
-0.041\end{array}$ & $\begin{array}{l}-0.028 \\
-0.133\end{array}$ \\
\hline FL & $\begin{array}{l}P \\
G\end{array}$ & & & & & $\begin{array}{l}- \\
-\end{array}$ & $\begin{array}{l}0.259 * \\
0.256 *\end{array}$ & $\begin{array}{l}-0.074 \\
-0.077\end{array}$ & $\begin{array}{l}-0.095 \\
-0.096\end{array}$ & $\begin{array}{l}-0.049 \\
-0.046\end{array}$ & $\begin{array}{l}0.051 \\
0.054\end{array}$ & $\begin{array}{l}0.013 \\
0.018\end{array}$ & $\begin{array}{l}-0.084 \\
-0.114\end{array}$ & $\begin{array}{l}0.209 \\
0.217\end{array}$ & $\begin{array}{l}0.124 \\
0.151\end{array}$ \\
\hline FD & $\begin{array}{l}P \\
G\end{array}$ & & & & & & $\begin{array}{l}- \\
-\end{array}$ & $\begin{array}{l}0.124 \\
0.133\end{array}$ & $\begin{array}{c}-0.237 \\
-0.263^{*}\end{array}$ & $\begin{array}{l}0.156 \\
0.186\end{array}$ & $\begin{array}{l}-0.548 * * \\
-0.591 * *\end{array}$ & $\begin{array}{l}-0.249 * \\
-0.263 *\end{array}$ & $\begin{array}{c}-0.194 \\
-0.257 *\end{array}$ & $\begin{array}{c}0.303^{*} \\
0.327^{*} *\end{array}$ & $\begin{array}{c}0.301^{*} \\
0.396^{* *}\end{array}$ \\
\hline AFW & $\begin{array}{l}P \\
G\end{array}$ & & & & & & & - & $\begin{array}{l}-0.363 * * \\
-0.382 * *\end{array}$ & $\begin{array}{l}-0.291 * \\
-0.296^{*}\end{array}$ & $\begin{array}{l}-0.197 \\
-0.198\end{array}$ & $\begin{array}{l}-0.211 \\
-0.219\end{array}$ & $\begin{array}{l}-0.333 * * \\
-0.376 * *\end{array}$ & $\begin{array}{l}0.309 * \\
0.311 *\end{array}$ & $\begin{array}{c}0.249 * \\
0.323^{*} *\end{array}$ \\
\hline NFPV & $\begin{array}{l}P \\
G\end{array}$ & & & & & & & & $\begin{array}{l}- \\
-\end{array}$ & $\begin{array}{l}0.074 \\
0.080\end{array}$ & $\begin{array}{l}0.338 * * \\
0.360 * *\end{array}$ & $\begin{array}{l}0.192 \\
0.229\end{array}$ & $\begin{array}{l}0.259^{*} \\
0.316^{*}\end{array}$ & $\begin{array}{l}0.661 * * \\
0.707 * *\end{array}$ & $\begin{array}{l}0.581^{* *} \\
0.806^{* *}\end{array}$ \\
\hline VL & $\begin{array}{l}P \\
G\end{array}$ & & & & & & & & & $\begin{array}{l}- \\
-\end{array}$ & $\begin{array}{l}-0.037 \\
-0.039\end{array}$ & $\begin{array}{l}0.282 * \\
0.298 *\end{array}$ & $\begin{array}{r}-0.014 \\
-0.017\end{array}$ & $\begin{array}{l}0.155 \\
0.158\end{array}$ & $\begin{array}{l}0.162 \\
0.243\end{array}$ \\
\hline NSPF & $\begin{array}{l}P \\
G\end{array}$ & & & & & & & & & & $\begin{array}{l}- \\
-\end{array}$ & $\begin{array}{c}0.355^{*} \\
0.365 * *\end{array}$ & $\begin{array}{l}-0.055 \\
-0.060\end{array}$ & $\begin{array}{c}0.301 * \\
0.302\end{array}$ & $\begin{array}{l}0.323 * * \\
0.427 * *\end{array}$ \\
\hline $1000 \mathrm{SW}$ & $\begin{array}{l}P \\
G\end{array}$ & & & & & & & & & & & $\begin{array}{l}- \\
-\end{array}$ & $\begin{array}{c}0.272^{*} \\
0.326 * *\end{array}$ & $\begin{array}{l}0.342 * * \\
0.351 * *\end{array}$ & $\begin{array}{c}0.275^{*} \\
0.372 * *\end{array}$ \\
\hline TSS & $\begin{array}{l}P \\
G\end{array}$ & & & & & & & & & & & & $\begin{array}{l}- \\
-\end{array}$ & $\begin{array}{l}0.512 * * \\
0.575 * *\end{array}$ & $\begin{array}{c}0.179 \\
0.295^{*}\end{array}$ \\
\hline FYPV & $\begin{array}{l}P \\
G\end{array}$ & & & & & & & & & & & & & $\begin{array}{l}- \\
-\end{array}$ & $\begin{array}{l}0.761 * * \\
.0 .990 * *\end{array}$ \\
\hline FYPH & $\begin{array}{l}P \\
G\end{array}$ & & & & & & & & & & & & & & $\begin{array}{l}- \\
-\end{array}$ \\
\hline
\end{tabular}

*Significant at $5 \%$ level of significance **Significant at $1 \%$ level of significance

$\mathrm{DFF}=$ Days to $50 \%$ flowering, $\mathrm{DFFF}=$ Days to first female flowering, NNFFF $=$ Nodes number at first female flower appears, $\mathrm{DFH}=\mathrm{Days}$ to first harvest, FL $=$ Fruit length $(\mathrm{cm}), \mathrm{FD}=$ Fruit diameter $(\mathrm{cm}), \mathrm{AFW}=$ Average fruit weight $(\mathrm{g}), \mathrm{NFPV}=$ Number of fruits per vines, VL= Vine length $(\mathrm{m})$, NSPF $=\mathrm{Number}$ of seeds per fruit, $1000 \mathrm{sw}=1000$ seed weight $(\mathrm{g}), \mathrm{TSS}=$ Total soluble solids $\left({ }^{\circ} \mathrm{brix}\right), \mathrm{FYPV}=$ Fruit yield per vine and FYPH $=$ Fruit yield per hectare $(\mathrm{q} / \mathrm{ha})$. 
Table.3 Estimation of direct and indirect effects of different characters on fruit yield in local cucumber (Cucumis sativus L.)

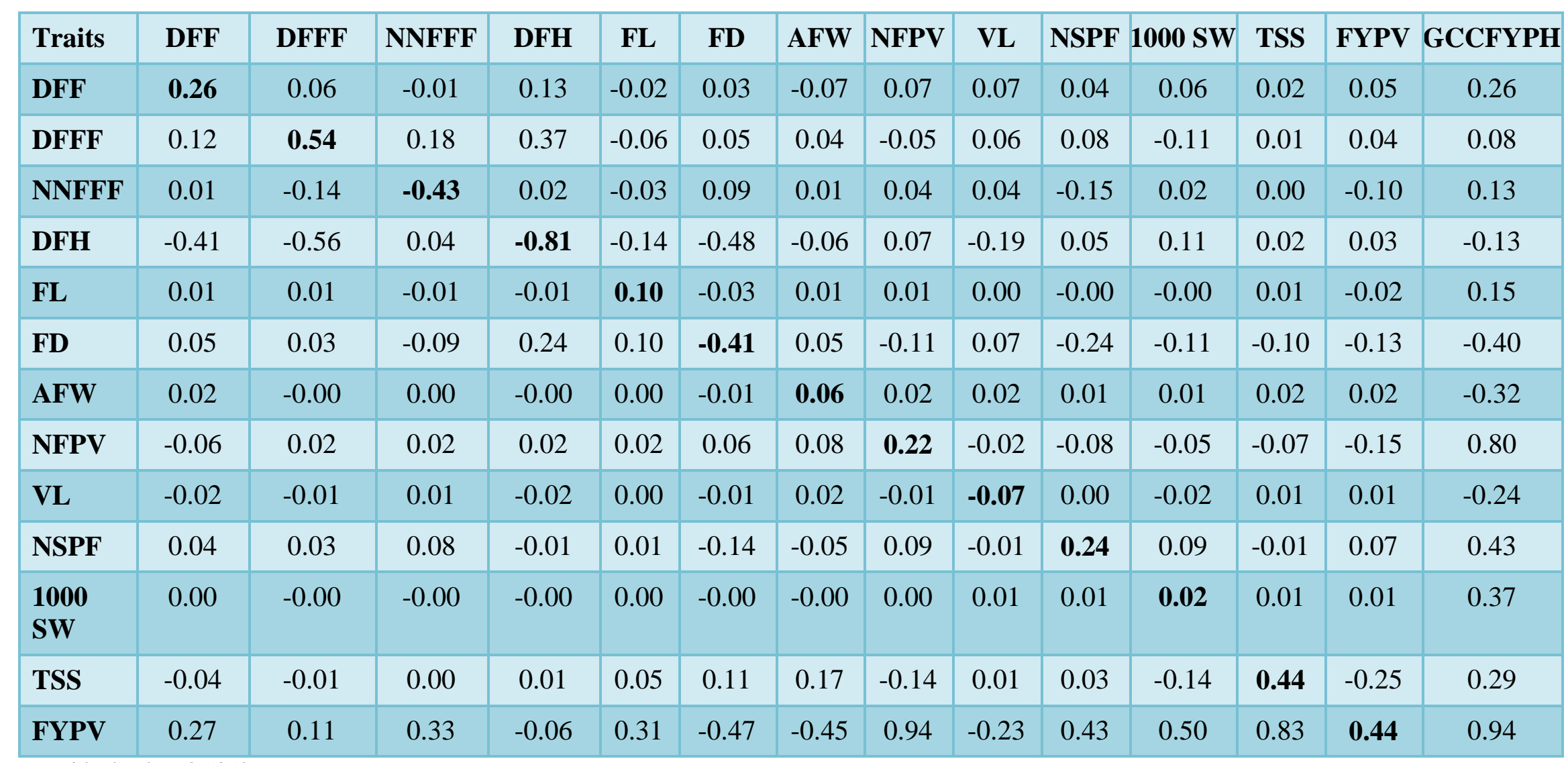

Residual value: 0.5352

$\mathrm{DFF}=$ Days to $50 \%$ flowering, $\mathrm{DFFF}=$ Days to first female flowering, NNFFF $=$ Nodes number at first female flower appears, $\mathrm{DFH}=\mathrm{Days}$ to first harvest, $\mathrm{FL}=$ Fruit length $(\mathrm{cm}), \mathrm{FD}=$ Fruit diameter $(\mathrm{cm})$, AFW $=$ Average fruit weight $(\mathrm{g}), \mathrm{NFPV}=\mathrm{Number}$ of fruits per vines, VL= Vine length $(\mathrm{m}), \mathrm{NSPF}=\mathrm{Number}$ of seeds per fruit, $1000 \mathrm{sw}=1000$ seed weight $(\mathrm{g})$, TSS $=$ Total soluble solids ( ${ }^{\text {brix }}$ ), FYPV $=$ Fruit yield per vine and GCCFYPH $=$ Genotypic correlation coefficient of Fruit yield per hectare (q/ha) 
Maximum positive indirect effect towards fruit yield per hectare was shown by number of fruits per vine via fruit yield per vine $(0.94)$ followed by total soluble solids via fruit yield per vine (0.83), 1000 seed weight via fruit yield per vine (0.50), number of seeds per fruit via fruit yield per vine (0.43) and days to first harvest via days to first female flowering (0.37) was observed. The results are in agreement with earlier results of Pal et al., (2017), Ahirwar et al., (2017), Kandasamy (2017), Choudhary et al., (2015), Kumar et al., (2013). The very low residual value depicted that the influence of traits other than those taken into account in the present study had very less effect on yield/ha.

\section{References}

Ahirwar, C.S., Singh, D.K. and Kushwaha, M.L. 2017. Assessment of genetic variation in cucumber (Cucumis sativus L.) germplasm on correlation, path analysis and cluster analysis, Chemical Science Review and Letters, 6(23): 1886-1893.

Allard, R. W. 1960 (a). Principles of plant breeding. John Wiley and Sons, Inc. New York, pp: 253.

Allard, R. W. 1960 (b). Principles of Plant Breeding. John Wiley and Sons. Inc. New York, pp. 485.

Arunkumar, K. H., Patil, M. G., Hanchinamani, C. N., Goud, I. S. and Hiremath, S. V. 2011. Genetic relationship of growth and development traits with fruit yield in $F_{2}$ population of BGDL $\times$ hot season of cucumber (Cucumis sativus L.). Karnataka Journal of Agricultural Sciences, 24(4): 497-500.

Arunkumar, K. H., Ramanjinapa, V. and Ravishankar, M. 2011. Path coefficient analysis in $\mathrm{F}_{2}$ population of cucumber (Cucumis sativus L.). Plant Archives, 11: 471-474.

Basavarajeshwari, M. R., Nagaraja, K. S., Srikanth, L. G., Mahamad, T. H. N and Shivanigapp K. 2014. Genetic variability, heritability and genetic advance for growth and earliness parameters in cucumber
(Cucumis sativus L.). Trends in Biosciences, 7(15): 1968-1970.

Bhardwaj, R. K. and Kumar, S. 2012. Studies on correlation between yield and seed characters in cucumber (Cucumis sativus L.). International Journal of Farm Sciences, 2(1): 54-58.

Burton, G. W. and DeVane, E. H. 1953. Estimating heritability in tall Fescue (Festuca arundiaceae) from replicated clonal material. Agronomy Journal, 45: 478-481.

Choudhary, H., Singh, D.K. And Damke, S.R. 2015. Genetic variability study in Cucumis sativus var. hardwickii: Key to cucumber improvement. International Journal of Basic and Applied Agricultural Research,13: 340-343.

Gaikwad, A. G., Musmade, A. M, Dhumal, S. S. and Sonawane, H.G. 2011. Variability studies in cucumber (Cucumis sativus L.). Ecology Environment and Conservation, 17(4): 799-802.

Gomez, K. A. and Gomez, A. A. 1976. Statistical Procedure for Agricultural Research, pp. 680. John Wiley and Sons, Inc. New York.

Hasan, M. J., Ullah, M. Z., Chouwdhury, A. Z. M. K. A., Saki, A. I. and Rahman, A. H. A. M. 2012. Genetic variability and correlation in exotic cucumber (Cucumis sativus L.) verities. Bangladesh Journal of Plant Breeding and Genetics, 25(1): 1723.

Johnson, H. W., Robinson, H. F. and Comstock, R. E. 1955. Estimates of genetic and environmental variability in soyabean. Agronomy Journal, 47: 314-318.

Kandasamy, R. 2017. Variability studies in cucumber (Cucumis sativus L.), Asian Journal of Horticulture, 12(1): 84-87.

Khan, Z., Shah, A. H., Gul, R., Majid, A., Khan, U. and Ahmad, H. 2015. Morphoagronomic characterization of cucumber germplasm for yield and yield associated traits. International Journal of Agronomy and Agricultural Research, 6(1): 1-6.

Khulakpam, N. S., Singh, V. and Rana, D. K. 2015. Medicinal importance of cucurbitaceous Crops. International Research Journal of Biological Sciences, 4(6): 1-3. 
Kumar, S., Kumar, D., Kumar, R., Thakur, K. S., Dogra, B. S. (2013). Estimation of genetic variability and divergence for fruit yield and quality traits in cucumber (Cucumis sativus L.) in North-Western Himalayas, Universal Journal of Plant Science, 1(2): 27-36.

Kumar, S., Kumar, R., Gupta, R. K. and Sephia, R. 2011. Studies on correlation and path coefficient analysis for yield and its contributing traits in cucumber. Crop Improvement, 38(1): 18-23.

Pal, S., Sharma, H. R., Das, A. and Pandav, A. K. 2017. Character association and path analysis for fruit yield and it's contributing traits in cucumber (Cucumis sativus L.), International Journal of Agriculture, Environment and Biotechnology, 10(2): 163-170.

Pal, S., Sharma, H. R., Rai, A.K. and Bhardwaj, R. K. 2016. Genetic variability, heritability and genetic gain for yield and quality traits in cucumber (Cucumis sativus L.). An International Quarterly Journal of Life Sciences, 11: 1985-1990.

Ranjan, P., Gangopadhay, K. K., Bag, M. K., Roy, A., Srivastava, R., Bhardwaj, R. and Dutta, M. 2015. Evaluation of cucumber (Cucumis sativus L.) germplasm for agronomic traits and disease resistance and estimation of genetic variability. Indian Journal of Agricultural Sciences, 85(2): 234-239.

Reshma, A. N., Hossain, M. K. 2011. Variability and correlation studies in short cucumber (Cucumis sativus L.). Jahangirnagar UniversityJournal of Biological Sciences,
23(2):33-37.

Robinson, H. F. 1966. Quantitative genetics in relation to breeding on the centennial of mendelism. Indian Journal of Genetics and Plant Breeding, 26(1): 171-187.

Robinson, R W. and Deckers Walter, D. S. 1999. Cucurbits. $C A B$ International. University Press, Cambridge. 483p.

Shukla, I. N., Shunder, S., Singh, D. K., Singh, N., Pandey, R. and Awasti, P.N. 2010. Genetic variability and selection parameters for fruit yield in cucumber (Cucumis sativus L.). CurrentAdvances in Agricultural Sciences, 2(2): 107-108

Ullah, M. Z., Hasan, M. J., Chowdhury, A. Z. K. M. A., Saki, A. I. and Rahman, A. H. M A. 2012. Genetic variability and correlation in exotic cucumber (Cucumis sativus L.) varieties. Bangladesh Journal of Plant Breeding and Genetics, 25(1): 1723.

Veena, R., Sidhu, A. S., Pitchaimuthu, M. and Souravi, K. 2013. Character association for fruit yield and yield traits in cucumber (Cucumis sativus L.). Electronic Journal of Plant Breeding,4(1): 1108-1112.

Yawalkar, K. S. 1985. Vegetable Crops of India. Agri-Horticultural Publishing House, Nagpur. 300p.

Yogesh, C., Yadav, S. K., Brijpal, B. and Dixit, S. K. 2009. Genetic variability, heritability and genetic advance for some traits in cucumber. Indian Journal of Horticulture, 66(4): 488-4.

\section{How to cite this article:}

Raman Thappa, Sanjeev Kumar and Samnotra, R. K. 2020. Character Association Studies for Various Characters in Local Cucumber (Cucumis sativus L.) under Subtropical Regions of Jammu. Int.J.Curr.Microbiol.App.Sci. 9(10): 3018-3026.

doi: https://doi.org/10.20546/ijcmas.2020.910.363 